\title{
SPATIO-TEMPORAL ECOLOGICAL AND EVOLUTIONARY DYNAMICS IN NATURAL BUTTERFLY POPULATIONS (2015 FIELD SEASON)
}

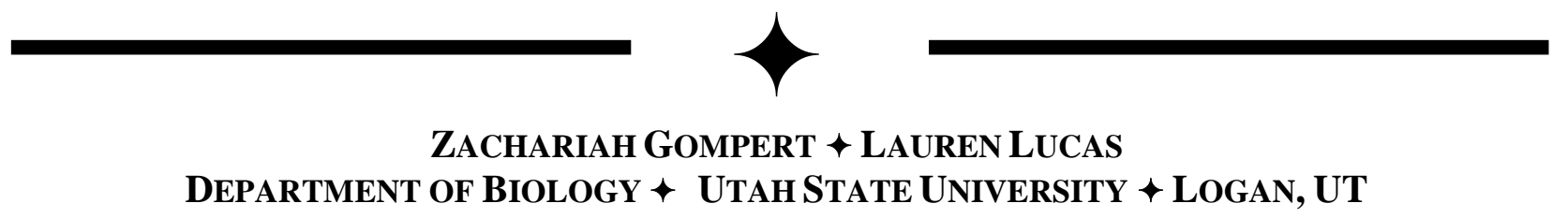

\section{$\downarrow \quad$ INTRODUCTION}

The study of evolution in natural populations has advanced our understanding of the origin and maintenance of biological diversity. For example, long term studies of wild populations indicate that natural selection can cause rapid and dramatic changes in traits, but that in some cases these evolutionary changes are quickly reversed when periodic variation in weather patterns or the biotic environment cause the optimal trait value to change (e.g., Reznick et al. 1997, Grant and Grant 2002). In fact, spatial and temporal variation in the strength and nature of natural selection could explain the high levels of genetic variation found in many natural populations (Gillespie 1994, Siepielski et al. 2009). Long term studies of evolution in the wild could also be informative for biodiversity conservation and resource management, because, for example, data on short term evolutionary responses to annual fluctuations in temperature or rainfall could be used to predict longer term evolution in response to directional climate change. Most previous research on evolution in the wild has considered one or a few observable traits or genes (e.g., Kapan 2001, Grant and Grant 2002, Barrett et al. 2008). We believe that more general conclusions regarding the rate and causes of evolutionary change in the wild and selection's contribution to the maintenance of genetic variation could be obtained by studying genome-wide molecular evolution in a suite of natural populations. Thus, in 2012 we began a long term study of genomewide molecular evolution in a series of natural butterfly populations in the Greater Yellowstone Area (GYA). This study will allow us to quantify the contribution of environment-dependent natural selection to evolution in these butterfly populations and determine whether selection consistently favors the same alleles across space and through time.
The focal species, Lycaeides idas, is one of five nominal species of Lycaeides butterflies that occur in North America (Figure 1; Nabokov 1949, Guppy and Shepard 2001, Gompert et al. 2006). These species are descended from one or more Eurasian ancestors that colonized North America about 2.4 million year ago (Vila et al. 2011). Lycaeides idas hybridizes with a second species, L. melissa, in the GYA (Gompert et al. 2010, 2012). Lycaeides idas is a holarctic species that is found in Alaska, Canada, and the central and northern Rocky Mountains of the contiguous USA (Scott 1986). Lycaeides idas is univoltine and adults generally fly from mid-July to early August. In the GYA $L$. idas populations often occupy mesic forest and montane habitat at elevations ranging from 2000-3500 m above sea level. Most populations of $L$. idas in the GYA feed on Astragalus miser as larvae, but some populations feed on other native legumes (most notably, other species of Astragalus and Lupinus; Gompert et al. 2010). We selected L. idas as the focal species for this study because of our experience with this species, extensive data on the location and natural history of $L$. idas populations, the availability of genomic resources for this species, and several key aspects of this species's natural history (e.g., L. idas have non-overlapping generations with one generation per year, well-defined populations, and modest genome sizes, and L. idas are found in various different habitats that might experience different environment-dependent selection pressures).

The specific goals of this study are to: (i) quantify genetic variation and molecular evolution in L. idas and their relationship with population size and environmental variation across space (i.e., different populations) and through time (i.e., from generation to generation) and (ii) test the hypothesis that the nature and strength of environment-dependent selection 
varies among populations and over generations and that this variation is sufficiently large to contribute to the maintenance of genetic variation in L. idas. This report documents the results from the fourth year of this long term study. The first year (2012) was a pilot study in which we collected L. idas for DNA sequencing and tested the distance sampling technique to estimate population sizes (population size is an important parameter for our evolutionary models). In our second year (2013) we collected L. idas and started distance sampling at four populations. In 2014 we collected L. idas and used distance sampling at ten populations. This year, 2015, we visited our ten focal populations for collected L. idas from our ten focal populations to sample individuals for future genetic work. We will estimate population sizes most years, but did not in 2015 .

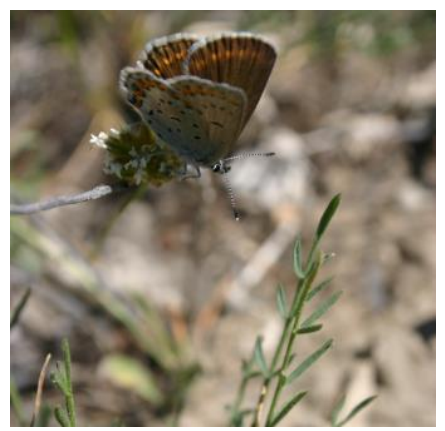

Figure 1. Photograph of a female $L$. idas butterfly perched above its host plant (Astragalus miser) on Blacktail Butte (BTB).

\section{$\uparrow \quad$ METHODS}

We collected 384 specimens from the ten populations involved in this study between July 10-26, 2015 (Figure 2, Table 1). Four of the populations are within park boundaries (BTB and RNV in GTNP and $\mathrm{BNP}$ and $\mathrm{HNV}$ in YNP). We are storing these whole adult butterflies at $-80^{\circ} \mathrm{C}$ for later DNA extraction and sequencing.

\section{$\uparrow \quad$ RESULTS}

We collected 29 males and 12 females from BCR, 35 males and 14 females from BNP, 30 males and 20 females from BTB, 24 males and 26 females from GNP, 17 males and 7 females from HNV, 39 males and 11 females from MRF, 22 males and 16 females from PSP, one male and one female from RNV, 22 males and 4 females from SKI, and 42 males and 8 females from USL. We were unable to

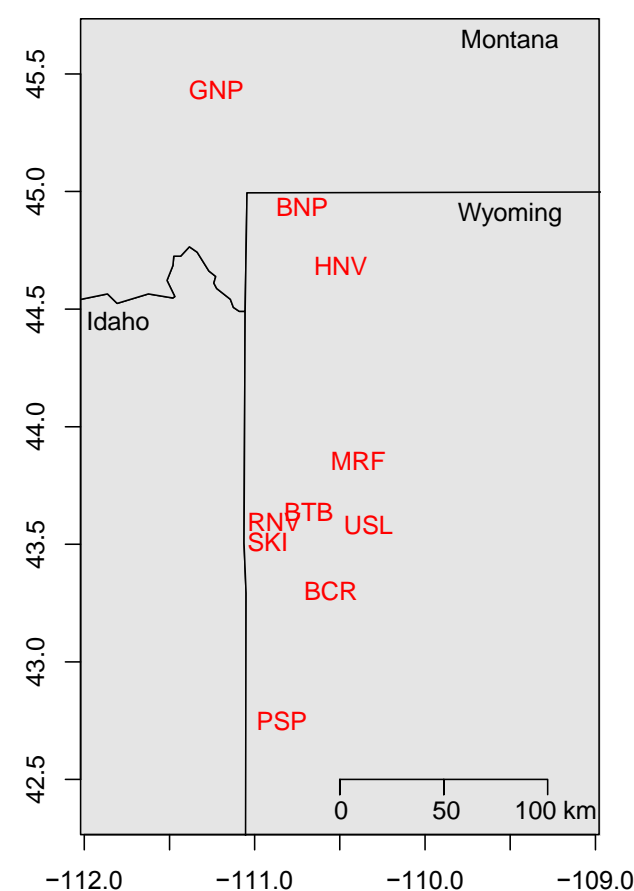

Figure 2. Map of the ten L. idas populations in the GYA involved in this long term study.

collect our target 50 individuals from our two higherelevation populations, HNV (2344 m) and RNV (2894 $\mathrm{m})$; the low snowpack for 2015 shifted the adult butterfly flight season so that it did not overlap with our time in the field.

Here in Table 1 we include our population size estimates from distance sampling in summers 2013-2014 (Buckland et al. 2001, Royle 2004; distsamp function in the unmarked $R$ package), as well as average host-plant abundance collected during those years. To characterize climate, we used 19 weather variables averaged over 1950-2000 (source: http://www.worldclim.org/bioclim), summarized as one variable via a Principal Component Analysis (PCA) using the prcomp function in $R$, which represented $52.6 \%$ of the variance in the original dataset. Refer to our 2014 report for further details. When comparing estimates between 2013 and 2014, we observed that GNP and BTB stayed about the same, BNP increased, and BCR decreased (Table 1). The range of host-plant abundance across sites was 0.21 to 0.92 , with the highest abundance at BNP and the lowest at MRF (Table 1). The climate variable ranged from -.91 to 5.69 across sites. Negative numbers represent hotter and drier climates, whereas positive values represent colder and wetter climates. We found that PSP and BCR were the hottest/driest. 
PSP was -3.91 and BCR was -3.75 . The coldest and wettest were RNV at 5.69 and GNP at 3.55 (Table 1). We found no relationship between 2014 population sizes and long term climate and average host-plant abundance. Our p-values were 0.4648 (host-plant) and 0.2052 (climate), both of which are well above 0.05 .

Table 1. Population names with abbreviations, population size estimates via distance sampling in 2013 and 2014, average host-plant abundance, and a representation of long term climate at each population. comparison of population size estimates in 2013 and 2014 are potentially interesting and could reflect demographic variability between years. The difference in habitat (i.e., host-plant) and climate across populations highlight the spatial variation in this study system. It is possible we would have seen a significant relationship between population size and weather specifically recorded from 2013 and 2014, but we currently don't have these data; we only have the bioclim data that is an average of the weather from 1950-2000.

\begin{tabular}{|c|c|c|c|c|}
\hline Population & $\begin{array}{l}2013 \\
\text { size }\end{array}$ & $\begin{array}{l}2014 \\
\text { size }\end{array}$ & $\begin{array}{c}\text { Ave. } \\
\text { host-plant } \\
\text { abundance }\end{array}$ & $\begin{array}{c}\text { Climate } \\
\text { PC } \\
\text { score }\end{array}$ \\
\hline $\begin{array}{l}\text { Blacktail } \\
\text { Butte } \\
\text { (BTB) }\end{array}$ & 1838.7 & 1978.5 & 0.5 & -1.5 \\
\hline $\begin{array}{l}\text { Bull Creek } \\
(\mathrm{BCR})\end{array}$ & 2382 & 1241.7 & 0.5 & -3.8 \\
\hline $\begin{array}{l}\text { Bunsen } \\
\text { Peak } \\
(\mathrm{BNP})\end{array}$ & 633.9 & 1273.2 & 0.9 & 1.2 \\
\hline $\begin{array}{l}\text { Garnet } \\
\text { Peak } \\
(\text { GNP) }\end{array}$ & 1119.9 & 1024.5 & 0.4 & 3.6 \\
\hline $\begin{array}{l}\text { Hayden } \\
\text { Valley } \\
\text { (HNV) }\end{array}$ & NA & 5291.4 & 0.3 & 1.1 \\
\hline $\begin{array}{l}\text { Mt. } \\
\text { Randolf } \\
\text { (MRF) }\end{array}$ & NA & 977.7 & 0.2 & -1.5 \\
\hline $\begin{array}{l}\text { Periodic } \\
\text { Springs } \\
(\mathrm{PSP})\end{array}$ & NA & 366.6 & 0.6 & -3.9 \\
\hline $\begin{array}{l}\text { Rendevous } \\
\text { Mountain } \\
(\mathrm{RNV})\end{array}$ & NA & NA & 0.3 & 5.7 \\
\hline $\begin{array}{ll}\text { Ski } & \text { Lake } \\
(\mathrm{SKI}) & \end{array}$ & NA & 1348.8 & 0.6 & 1.6 \\
\hline $\begin{array}{l}\text { Upper } \\
\text { Slide Lake } \\
\text { (USL) }\end{array}$ & NA & 1708.2 & 0.5 & -2.4 \\
\hline
\end{tabular}

We will continue this study during the 2016 summer field season. During this and subsequent field seasons, we will collect samples and estimate population sizes at all ten sites listed in Table 1 . We will also continue collecting habitat data that will be useful for fitting causal models of molecular evolution. We plan to begin DNA sequencing of the collected L. idas in 2016. We also will collaborate with both undergraduate and graduate researchers during the 2016 field season.

\section{$\uparrow \quad$ LiterATURE CITED}

Barrett, R.D.H., S.M. Rogers, and D. Schluter. 2008. Natural selection on a major armor gene in threespine stickleback. Science 322:255257.

Buckland, S.T., D.R. Anderson, K.P. Burnham, J.L. Laake, D.L. Borchers, and L. Thomas. 2001. Introduction to Distance Sampling: Estimating Abundance of Biological Populations. Oxford University Press, USA.

Gillespie, J.H. 1994. The Causes of Molecular Evolution. Oxford University Press, USA.

Gompert, Z, J.A. Fordyce, M.L. Forister, A.M. Shapiro, and C.C. Nice. 2006. Homoploid hybrid speciation in an extreme habitat. Science 314:1923-1925.

Gompert, Z., L.K. Lucas, J.A. Fordyce, M.L. Forister, and C.C. Nice. 2010. Secondary contact between Lycaeides idas and L. melissa in the Rocky Mountains: Extensive introgression and a patchy hybrid zone. Molecular Ecology 19:3171-3192.

Because we have not yet sequenced the DNA from the sampled butterflies, we cannot yet make any conclusions about the rates or causes of molecular evolution in these study populations. But we have already learned a few things from our previous distance sampling surveys and analyses. Based on our moderate population size estimates we predict that both genetic drift and selection are important drivers of evolution in this system (Lynch 2007). The

Gompert, Z., L.K. Lucas, C.C. Nice, J.A. Fordyce, and M.L. Forister. 2012. Genomic regions with a history of divergent selection affect fitness of hybrids between two butterfly species. Evolution 66:2167-2181.

Grant, P.R., and B.R. Grant. 2002. Unpredictable evolution in a 30-year study of Darwin's finches. Science 296:707-711. 
Guppy, C., and J. Shepard. 2001. Butterflies of British Columbia. UBC Press.

Lynch, M. 2007. The Origins of Genome Architecture. Sinauer Associates, Sunderland MA.

Kapan, D. 2001. Three-butterfly system provides a field test of müllerian mimicry. Nature 409: $338-340$.

Nabokov, V. 1949. The nearctic members of Lycaeides Hübner (Lycaenidae, Lepidoptera). Bulletin of the Museum of Comparative Zoology 101:479-541.

Reznick, D.N., F.H. Shaw, F.H. Rodd, and R.G. Shaw. 1997. Evaluation of the rate of evolution in natural populations of guppies (Poecilia reticulata). Science 275:1934-1937.
Royle. J.A., D.K. Dawson, and S. Bates. 2004. Modeling abundance effects in distance sampling. Ecology 85: 1591-1597.

Scott, J. 1986. The Butterflies of North America: A Natural History and Field Guide. Stanford University Press.

Siepielski, A.M., J.D. DiBattista, and S.M. Carlson. 2009. It's about time: The temporal dynamics of phenotypic selection in the wild. Ecology Letters 12:1261-1276.

Vila, R., C.D. Bell, R. Macniven, et al. 2011. Phylogeny and palaeoecology of Polyommatus blue butterflies show Beringia was a climate-regulated gateway to the New World. Proceedings of the Royal Society B: Biological Sciences 278:2737-2744. 